\title{
Distribution of high-density lipoprotein cholesterol according to age, sex, and ethnic origin: cardiovascular disease study in Finnmark 1977
}

\author{
DAG S THELLE, OLAV H FøRDE, AND EGIL ARNESEN \\ From the Institute of Community Medicine, University of Troms $\emptyset$, and the National Mass Radiography Service, \\ Oslo, Norway
}

SUMMARY As a part of a survey for cardiovascular risk factors high-density lipoprotein cholesterol (HDL-C) was determined in 15942 men and women aged 20-53. Women had on average $0.24 \mathrm{mmol} / \mathrm{l}$ higher HDL-C concentration than men. The difference was of the same magnitude at all ages. For both sexes HDL-C increased with age. The increase was partly influenced by other variables affecting the HDL-C concentration. After adjusting for the effect of height, weight, cigarette-smoking, physical activity in leisure time, and ethnic origin the age-related change was more pronounced, $0.13 \mathrm{mmol} / 1$ and $0.16 \mathrm{mmol} / 1$ difference between the youngest and the oldest age group for men and women respectively. The population comprised three ethnic groups. HDL-C did not differ among the women of different ethnic origin, but among men those of Lappish origin had higher HDL-C concentrations than the other groups. This difference was reduced after adjusting for other variables and was probably due more to external factors influencing the HDL-C concentration than specific ethnic-genetic traits.

The first cardiovascular disease survey in Finnmark County was done in $1974 .^{1}$ At the rescreening in 1977 high-density lipoprotein cholesterol (HDL-C) was included. The main purpose of the second study was to examine changes in coronary risk factors since the first screening and to establish a prospective study of sufficient size that included HDL-C. Increasing evidence that HDL-C may be a protective factor for coronary heart disease has stimulated interest in cross-sectional data, which can give information on HDL-C distribution in free-living populations and its relation to other factors. The present paper describes the distribution of HDL-C with regard to sex, age, and ethnic origin.

\section{Materials and methods}

A sample of men and women aged 20-53 in Finnmark were invited to attend the study. The sample sizes in different age groups are shown in table 1 . The total number invited were 20679 , and 17149 attended (83\%).

ETHNIC CLASSIFICATION

The participants were asked whether two or more of their grandparents were of Lappish or Finnish origin.
Table 1 Population invited and screened at the cardiovascular study in Finnmark in 1977

\begin{tabular}{|c|c|c|c|c|c|c|c|}
\hline \multirow{2}{*}{$\begin{array}{l}\text { Year of } \\
\text { birth }\end{array}$} & \multirow{2}{*}{$\begin{array}{l}\text { \% total } \\
\text { popula- } \\
\text { tion }\end{array}$} & \multicolumn{3}{|l|}{ Invited } & \multicolumn{3}{|c|}{ Screened } \\
\hline & & Men & Women & Total & Men & Women & Total \\
\hline $\begin{array}{l}1925-42 \\
1943-54 \\
1955-57\end{array}$ & $\begin{array}{r}100 \% \\
21 \% \\
10 \%\end{array}$ & $\begin{array}{r}7858 \\
3099 \\
213\end{array}$ & $\begin{array}{r}6700 \\
2622 \\
187\end{array}$ & $\begin{array}{r}14558 \\
5721 \\
400\end{array}$ & $\begin{array}{r}6660 \\
2090 \\
96\end{array}$ & $\begin{array}{r}6105 \\
2090 \\
108\end{array}$ & $\begin{array}{r}12765 \\
4180 \\
204\end{array}$ \\
\hline Total & & 11170 & 9509 & 20679 & 8846 & 8303 & 17149 \\
\hline
\end{tabular}

On the basis of the answers, "yes," "no," and "don't know," the subjects were grouped into five ethnic categories: Finnish (Finnish: yes; Lappish: no or don't know), Lappish (Lappish: yes; Finnish: no or don't know), Norse (Finnish: no; Lappish, no), Fin/Lap (Finnish: yes; Lappish: yes) and unknown (none of above). This is identical to the description given in the report from the first cardiovascular study in Finnmark. ${ }^{1}$

\section{SCREENING METHODS}

The procedures and methods were in general identical to those used in the first study in Finnmark. ${ }^{2}$ The main features were a self-administered questionnaire and measurements of weight, height, 
blood pressure, and serum lipid and blood glucose concentrations.

\section{LABORATORY METHODS}

The handling of the blood samples has been described. ${ }^{2}$ In four municipalities each non-fasting blood sample was divided into two aliquots. One aliquot was stored at $+4^{\circ} \mathrm{C}$ and analysed within two weeks for HDL-C at the Institute of Medical Biology in Troms $\varnothing$ (total: 4480). The other aliquot was sent to Ulleval Hospital in Oslo for determination of total cholesterol, triglycerides, and glucose. In the rest of the county the whole serum sample was sent directly to Oslo (total: 11 462). The serum remnants after the analysis in Oslo were stored at $-20^{\circ} \mathrm{C}$ for 12 months before HDL-C determinations were done in Troms $\emptyset$.

HDL-C was assayed after precipitation with heparin and $\mathrm{MnCl}_{2}{ }^{3}$ by the cholesterol-esterase cholesterol-oxidase method ${ }^{4}$ using a commercial kit (Boehringer Mannheim) and pure cholesterol standards. Lipaemic samples were diluted with $0.15 \mathrm{mmol} / \mathrm{l} \mathrm{NaCl}$. Precilip (Boehringer Mannheim) was used for quality control. The coefficient of variation for replicated measurements of HDL-C was 2.7\%. HDL-C concentrations were available for 15942 subjects.

\section{ADJUSTMENT OF HDL-C VALUES}

The serum samples were analysed in two batches (the first analysed within two weeks and the other after one year of frozen storage). The average HDL-C value was lower in the stored batch. This could be due to a systematic analytical error or to the effect of storage as well as to demographic differences between the two populations.

The percentile specific comparison between the two batches showed that the absolute difference was of the same magnitude in all percentiles, indicating an additive constant bias in the assay rather than a relative reduction. The batch number was therefore introduced in a multiple regression analysis of HDL-C together with serum triglycerides, total cholesterol, ethnic groups, sex, age, number of cigarettes smoked, leisure physical activity, height, and weight. The differences between the batches ranged from 0.11 to $0.13 \mathrm{mmol} / 1$ in different subgroups of sex and age when all other variables were controlled. A value of $0.12 \mathrm{mmol} / 1$ was therefore added to the HDL-C values in the "frozen" batch.

\section{Results}

Table 2 shows the mean HDL-C values according to the diagnosis and symptoms reported in the self-administered questionnaire. The proportion of
Table 2 Age-adjusted mean HDL-C concentration (mmol/l) according to self-reported diagnoses and symptoms, Finnmark 1977

\begin{tabular}{lrrrrrr}
\hline & \multicolumn{2}{l}{ Women } & & \multicolumn{2}{l}{ Men } \\
\cline { 2 - 3 } \cline { 5 - 6 } Disease category & No & $\bar{x}$ & & No & $\bar{x}$ \\
\hline Myocardial infarction & 8 & 1.39 & & 79 & 1.18 \\
Angina pectoris & 74 & 1.35 & & 95 & 1.15 \\
Other heart disease & 53 & 1.52 & & 35 & 1.28 \\
Cerebrovascular stroke & 14 & 1.46 & & 15 & 1.08 \\
Atherosclerosis obliterans & 17 & 1.52 & & 18 & 1.37 \\
Diabetes mellitus & 24 & 1.32 & & 38 & 1.33 \\
Hypertension (on treatment) & 304 & 1.41 & & 201 & 1.22 \\
Effort-induced chest pain & 164 & 1.48 & & 175 & 1.24 \\
Effort-induced leg pain & 113 & 1.46 & & 72 & 1.32 \\
"Healthy" (none of above) & 6978 & 1.53 & & 7482 & 1.29 \\
Standard deviation & & & 0.37 & & 0.35 \\
\hline
\end{tabular}

"Reported on self-administered questionnaire.

men $(10.3$ per 1000$)$ reporting myocardial infarction was 10 times that of women (1.1 per 1000), but among the women 43 per 1000 were on treatment for high blood pressure compared with 27 per 1000 among the men.

Subjects who reported myocardial infarction, angina pectoris, current treatment for high blood pressure, or a previous stroke had a lower mean HDL-C value than the healthy group (for each category $p<0.05$ ), who were those subjects who did not report diseases or symptoms tabulated in table 2 .

Female diabetics also had low HDL-C whereas their male counterparts had a mean level similar to the healthy group.

HDL-C mean values for the healthy group are shown according to age, ethnic origin, and sex in tables 3 and 4 . Women had a mean HDL-C value $0.24 \mathrm{mmol} / \mathrm{l}$ higher than the men. The sex differences varied between 0.18 and $0.28 \mathrm{mmol} / 1$ in the different age groups. In both sexes there was an age-related increase in mean HDL-C value. A multiple covariance analysis was performed for each sex separately to examine this age-related relationship more closely. The analysis was done with weight, height, and number of cigarettes smoked daily as covariates and five-year age groups, ethnic origin, current cigarette smoking, and physical activity at leisure as factors. The mean HDL-C concentrations for each age group were adjusted for all other factors and covariates. The analysis was performed with the Statistical Package for the Social Science subprogram ANOVA. ${ }^{5}$ In the figure are displayed these adjusted and unadjusted mean values. Unadjusted, the HDL-C concentration increased by $0.10 \mathrm{mmol} / \mathrm{l}$ from the youngest to the oldest age group of the women. This difference increased to 0.16 when adjusted for the three mentioned variables. In the men the unadjusted increase was $0.07 \mathrm{mmol} / \mathrm{l}$ and the adjusted value 
Table 3 High-density lipoprotein cholesterol (mmol/l) in healthy men according to age and ethnic origin, Finnmark 1977

\begin{tabular}{|c|c|c|c|c|c|c|c|c|c|c|c|c|}
\hline \multirow[b]{2}{*}{ Age } & \multicolumn{2}{|c|}{ Finnish } & \multicolumn{2}{|c|}{ Lappish } & \multicolumn{2}{|l|}{ Norse } & \multicolumn{2}{|c|}{ Fin/Lap } & \multicolumn{2}{|c|}{ Unknown } & \multicolumn{2}{|l|}{ Total } \\
\hline & No & Mean & No & Mean & No & Mean & No & Mean & No & Mean & No & Mean \\
\hline $\begin{array}{l}20-24 \\
25-29 \\
30-34 \\
35-39 \\
40-44 \\
45-49 \\
50-53\end{array}$ & $\begin{array}{r}43 \\
132 \\
147 \\
290 \\
269 \\
295 \\
143\end{array}$ & $\begin{array}{l}1 \cdot 27 \\
1 \cdot 27 \\
1 \cdot 31 \\
1 \cdot 26 \\
1 \cdot 29 \\
1 \cdot 33 \\
1 \cdot 37\end{array}$ & $\begin{array}{r}58 \\
128 \\
100 \\
207 \\
210 \\
216 \\
105\end{array}$ & $\begin{array}{l}1 \cdot 25 \\
1 \cdot 36 \\
1 \cdot 25 \\
1 \cdot 32 \\
1 \cdot 38 \\
1 \cdot 41 \\
1 \cdot 37\end{array}$ & $\begin{array}{l}147 \\
394 \\
465 \\
943 \\
685 \\
724 \\
469\end{array}$ & $\begin{array}{l}1 \cdot 29 \\
1 \cdot 24 \\
1.22 \\
1.26 \\
1 \cdot 25 \\
1.30 \\
1 \cdot 30\end{array}$ & $\begin{array}{l}16 \\
32 \\
38 \\
77 \\
77 \\
60 \\
40\end{array}$ & $\begin{array}{l}1 \cdot 27 \\
1 \cdot 23 \\
1 \cdot 20 \\
1 \cdot 29 \\
1.27 \\
1.36 \\
1.40\end{array}$ & $\begin{array}{r}48 \\
92 \\
95 \\
223 \\
200 \\
201 \\
113\end{array}$ & $\begin{array}{l}1 \cdot 24 \\
1 \cdot 25 \\
1 \cdot 15 \\
1 \cdot 29 \\
1.33 \\
1 \cdot 37 \\
1 \cdot 37\end{array}$ & $\begin{array}{r}312 \\
778 \\
845 \\
1740 \\
1441 \\
1496 \\
870\end{array}$ & $\begin{array}{l}1 \cdot 27 \\
1 \cdot 27 \\
1.24 \\
1 \cdot 27 \\
1.29 \\
1.33 \\
1 \cdot 33\end{array}$ \\
\hline $\begin{array}{l}\text { Total } \\
\text { Standard deviation }\end{array}$ & 1319 & $\begin{array}{l}1.30 \\
0.35\end{array}$ & 1024 & $\begin{array}{l}1.35 \\
0.39\end{array}$ & 3827 & $\begin{array}{l}1 \cdot 27 \\
0 \cdot 34\end{array}$ & 340 & $\begin{array}{l}1.30 \\
0.33\end{array}$ & 972 & $\begin{array}{l}1 \cdot 31 \\
0 \cdot 34\end{array}$ & 7482 & $\begin{array}{l}1.29 \\
0.35\end{array}$ \\
\hline
\end{tabular}

Table 4 High-density lipoprotein cholesterol (mmol/l) in healthy women according to age and ethnic origin, Finnmark 1977

\begin{tabular}{|c|c|c|c|c|c|c|c|c|c|c|c|c|}
\hline \multirow[b]{2}{*}{ Age } & \multicolumn{2}{|c|}{ Finnish } & \multicolumn{2}{|c|}{ Lappish } & \multicolumn{2}{|l|}{ Norse } & \multicolumn{2}{|c|}{ Fin/Lap } & \multicolumn{2}{|c|}{ Unkown } & \multicolumn{2}{|l|}{ Total } \\
\hline & No & Mean & No & Mean & No & Mean & No & Mean & No & Mean & No & Mean \\
\hline $\begin{array}{l}20-24 \\
25-29 \\
30-34 \\
35-39 \\
40-44 \\
45-49 \\
50-53\end{array}$ & $\begin{array}{r}71 \\
128 \\
119 \\
272 \\
245 \\
258 \\
133\end{array}$ & $\begin{array}{l}1.48 \\
1.53 \\
1.47 \\
1.55 \\
1.55 \\
1.56 \\
1.57\end{array}$ & $\begin{array}{r}58 \\
131 \\
122 \\
188 \\
179 \\
182 \\
86\end{array}$ & $\begin{array}{l}1.47 \\
1.47 \\
1.50 \\
1.52 \\
1.53 \\
1.52 \\
1.59\end{array}$ & $\begin{array}{l}150 \\
422 \\
407 \\
835 \\
668 \\
671 \\
373\end{array}$ & $\begin{array}{l}1.44 \\
1.50 \\
1.51 \\
1.56 \\
1.55 \\
1.56 \\
1.55\end{array}$ & $\begin{array}{l}16 \\
46 \\
39 \\
72 \\
66 \\
66 \\
34\end{array}$ & $\begin{array}{l}1.43 \\
1.55 \\
1.47 \\
1.47 \\
1.49 \\
1.47 \\
1.59\end{array}$ & $\begin{array}{r}46 \\
106 \\
94 \\
228 \\
177 \\
991 \\
97\end{array}$ & $\begin{array}{l}1.41 \\
1.46 \\
1.48 \\
1.54 \\
1.52 \\
1.56 \\
1.49\end{array}$ & $\begin{array}{r}341 \\
833 \\
781 \\
1595 \\
1335 \\
1370 \\
723\end{array}$ & $\begin{array}{l}1.45 \\
1.50 \\
1.50 \\
1.55 \\
1.54 \\
1.55 \\
1.56\end{array}$ \\
\hline $\begin{array}{l}\text { Total } \\
\text { Standard deviation }\end{array}$ & 1226 & $\begin{array}{l}1.54 \\
0.37\end{array}$ & 946 & $\begin{array}{l}1: 52 \\
0.35\end{array}$ & 3526 & $\begin{array}{l}1.54 \\
0.37\end{array}$ & 339 & $\begin{array}{l}1.50 \\
0.35\end{array}$ & 941 & $\begin{array}{l}1.52 \\
0.35\end{array}$ & 6978 & $\begin{array}{l}1 \cdot 53 \\
0.37\end{array}$ \\
\hline
\end{tabular}

$0 \cdot 13 \mathrm{mmol} / \mathrm{l}$. Thus for both sexes the age-related increase was more pronounced after adjusting for height, weight, and cigarette-smoking. The magnitude of the adjustments was similar in the two sexes. The dip observed for subjects aged $30-34$ is statistically significant for men $(p<0.05)$ but not for women.

In tables 3 and 4 are also seen differences in HDL-C between subjects of different ethnic origin. The largest differences were observed between the men of Lappish origin and those of Norse and Finnish origin. The most notable difference was that men of Lappish origin had the highest mean HDL-C value, $0.08 \mathrm{mmol} / \mathrm{l}$ higher than those of Norse and Finnish origin. After allowance for the effect of weight, height, and cigarette-smoking the difference was reduced to $0.06 \mathrm{mmol} / \mathrm{l}$. The major differences were observed for men aged 25-29 and 35-49. The analysis of covariance, however, did not show any interaction between age-related change and ethnic origin. Among the women only small and insignificant differences were observed.

\section{Discussion}

The serum analyses of HDL-C were done in two different batches one year apart. This introduced a bias that we have tried to correct. The correction may

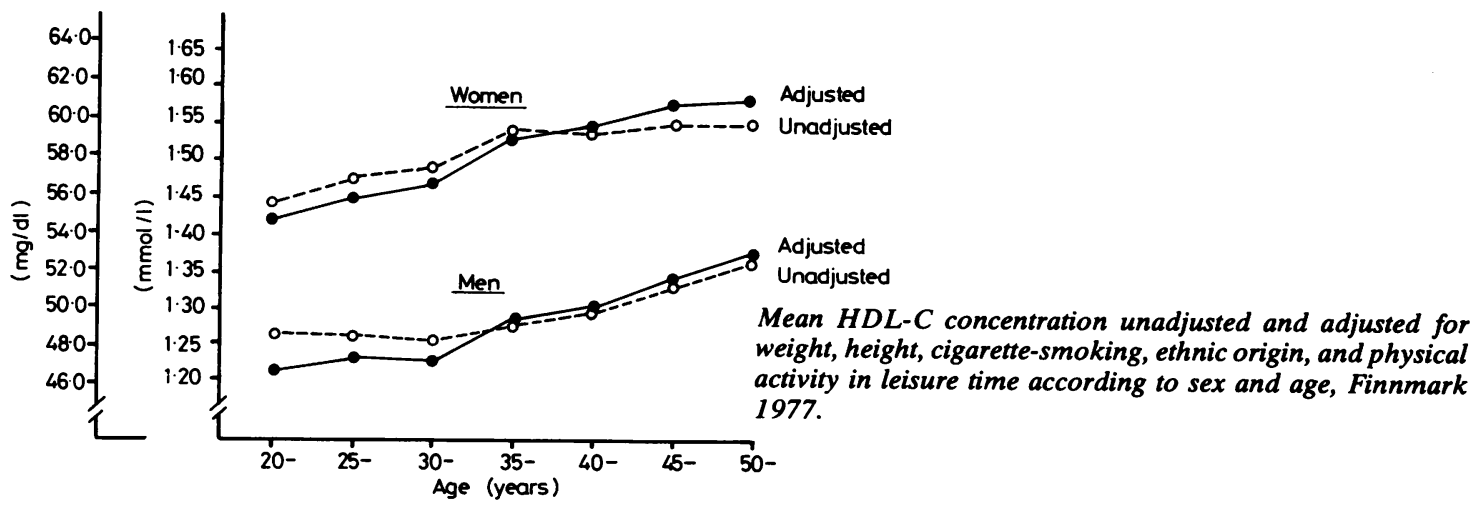


have introduced new biases that could influence the results. Nevertheless, identical statistical analysis of the data from the two batches separately gave the same conclusions as presented in this paper.

The difference observed in HDL-C concentrations between subjects reporting myocardial infarction or angina pectoris and the healthy group is small compared with what has been observed in prospective studies. ${ }^{b-8}$ There are two important restrictions in the present material which would both contribute to diminishing possible differences between subjects with atherosclerotic disorders and a healthy population; one is that the diagnoses are based on answers to a self-administered questionnaire and the "diseased" group probably contains a number of "false-positives"-that is, subjects who really are healthy but report disease. The other restriction is that those reporting a previous myocardial infarction are the survivors of a potentially fatal disorder, thus presumably those least afflicted in a population of patients with coronary heart disease. At least one study has shown a dose-response relationship between the degree of atherosclerosis and HDL-C, ${ }^{9}$ and one would expect that the survivors were the subjects closest to those who have remained healthy. Thus cases in the general population will usually tend to be less severely affected than clinical cases.

Other authors have reported that diabetics have lower HDL-C than non-diabetics. ${ }^{10}$ This was confirmed for the women in the present study but not for the men. Diabetes was the only disease category where the sex difference in HDL-C was negligible. One explanation for this finding may be an unequal distribution of insulin-dependent diabetics in the two sexes, as diabetics using insulin have normal or high HDL-C concentrations. ${ }^{11}$ The low HDL-C concentrations in diabetics may then be confined to the non-insulin-dependent subjects. The observation that subjects on antihypertensive treatments have decreased HDL-C values will be further elucidated in a separate report.

The pronounced sex difference in HDL-C value has been observed in many studies. The value is consistently higher in women of all ages after adolescence, and of a magnitude that may play some part in explaining the sex difference in incidence and mortality of coronary heart disease. ${ }^{12}$ The higher HDL-C concentration in women may be secondary to differences in hormonal level-for instance, in oestrogen which when given exogenously tends to increase HDL-C. ${ }^{13}$

The present material showed an important increase in HDL-C with age for both sexes but was mainly observed after the age of 30 . This increase was more pronounced when adjustments were done for the influence of cigarette smoking, weight, and height. The adjusted age-related curve for women is close to linearity, whereas the similar curve for men shows a dip at the age of 30-34. This cohort was born in the years 1943-7, a time during and just after the second world war that was an extremely difficult period in Finnmark county. Other studies have shown this cohort to be shorter than the neighbouring birth cohorts. ${ }^{14}$ This may suggest that living conditions during childhood and adolescence can determine your later HDL-C value as has already been suggested with regard to total cholesterol. ${ }^{15}$

Other cross-sectional studies describe the HDL-C concentration in men aged $20-54$ as stable, without any increase with age. For women, however, the results ${ }^{16}$ correspond with those reported in the present material. One might speculate if the discrepancy with regard to the men reflects a different influence of external factors in different populations, thus being the result of cohort effects. The enhanced age-related increase observed after adjustment for some variables would support this hypothesis, implying that the true (inherent) HDL-C change with age differs from the one observed in a cross-sectional survey. Neither the influence of diet nor alcohol intake have been assessed in this study. The influence of diet as described in other studies is far from clear, however, the main contribution seems to stem from the intake of carbohydrates and possibly, as recently reported, water intake. ${ }^{17}$ More consistent is the effect of alcohol consumption increasing HDL-C. ${ }^{18}$

The high correlation between alcohol intake and cigarette smoking, however, may lead to an underestimation of the contribution from cigarette smoking when alcohol is not controlled for. ${ }^{19}$ This is relevant to the adjusted age-related mean values presented in this study, but, as the relationship between alcohol intake and age is not known, no indication can be given as to the effect of this variable on the age-related changes.

There are some suggestions that men of Lappish descent may be less prone to coronary heart disease than men of the other ethnic groups in Finnmark. ${ }^{20}$ Previous work has not shown any consistent differences in coronary risk factor levels. ${ }^{21}$ The differences observed with regard to HDL-C in the present study were small and are further reduced when adjusted for the influence of other factors. This together with the fact that the differences mainly concerned the men may indicate that other factors than ethnic origin are responsible. At our present state of knowledge of HDL-C and risk of coronary heart disease, it seems doubtful that the reported differences between the ethnic groups would be of sufficient magnitude to result in real differences in the incidence of coronary heart disease. 
References

${ }^{1}$ National Mass Radiography Service, Health Services of Finnmark County, Ulleval Hospital, Faculty of Medicine, University of Troms $\varnothing$. The cardiovascular study in Finnmark 1974-1975 Nordic Council for Arctic Medical Research, 1979; 25.

${ }^{2}$ Bjartveit K, Foss OP, Gjervig T, Lund-Larsen PG. The cardiovascular disease study in Norwegian counties. Acta Med Scand 1979; 634, suppl: 1-70.

${ }^{3}$ Burstein M, Scholnick HR, Morfin R. Rapid method for the isolation of lipoproteins from human serum by precipitation with polyanions. J Lipid Res 1970; 11: 583-95.

${ }^{4}$ Röschlau P, Bernt E, Gruber W. Enzymatische Bestimmung des Gesamt-Cholesterins im Serum. Zeitschrift für Klinische Chemie und Klinische Biochemie 1974; 12: 403-7.

${ }^{5} \mathrm{Nie} \mathrm{HH}$. Statistical package for the social sciences. 2nd ed. New York: McGraw Hill Inc, 1975.

${ }^{6}$ Miller NE, Førde OH, Thelle DS, Mjøs OD. The Troms $\emptyset$ heart study. High density lipoprotein and coronary heart . disease: a prospective case-control study. Lancet 1977; i: 965-8.

${ }^{7}$ Gordon T, Castelli WP, Hjortland MC, Kannel WB, Dawber TR. High density lipoprotein as a protective factor against coronary heart disease. The Framingham study. Am J Med 1977; 62: 707-14.

${ }^{8}$ Goldbourt U, Medalie JH. High density lipoprotein cholesterol and incidence of coronary heart disease. The Israeli ischemic heart disease study. Am J Epidemiol 1979; 109: 296-308.

${ }^{9}$ Naito HK, Greenstreet RL, David JA, et al. HDLcholesterol concentration and severity of coronary atherosclerosis determined by cine-angiography. Artery 1980; 2: 101-12.

${ }^{10}$ Miller NE. The evidence for the antiatherogenicity of high density lipoprotein in man. Lipids 1978; 13: 914-9.

${ }^{11}$ Nikkilä EA, Hormila P. Serum lipids and lipoproteins in insulin treated diabetes. Diabetes 1978; 27: 1078-86.
${ }^{12}$ Beaglehole R, Trost DC, Tamir I, et al. Plasma high density lipoprotein cholesterol in children and young adults. Circulation 1980; 62, part II, (suppl IV): 83-92.

${ }^{13}$ Gustafson A, Svanborg A. Gonadal steroid effects on plasma lipoproteins and individual phospholipids. J Clin Endocrinol Metab 1972; 35: 203-7.

${ }^{14}$ Forsdahl A. Waaler HT. Body height changes by age. Tidsskr Nor Lageforen 1976; 96: 211-5.

${ }^{15}$ Forsdahl A. Living conditions in childhood and subsequent development of risk factors for arteriosclerotic heart disease. J Epidemiol Community Health 1978; 32: 34-7.

${ }^{16}$ Heiss G, Johnson NJ, Reiland S, Davis CE, Tyroler HA. The epidemiology of plasma high-density lipoprotein cholesterol levels. The lipid research clinics program prevalence study. Circulation 1980; 62, part II, (suppl IV): $116-36$.

${ }^{17}$ Dwyer T, Calvert GD, Baghurst KI, Leitch DR. Diet, other lifestyle factors and HDL cholesterol in a population of Australian male service recruits. Am J Epidemiol 1981; 114: 83-96.

${ }^{18}$ Ernst N, Fisher M, Smith W, et al. The association of plasma high-density lipoprotein cholesterol with dietary intake and alcohol consumption. The lipid research clinics program prevalence study. Circulation 1980; 62, part II (suppl IV): 41-52.

${ }^{19}$ Criqui MH, Wallace RB, Heiss G, Mishkel M, Schonfeld G, Jones GTL. Cigarette smoking and plasa highdensity lipoprotein cholesterol. The lipid research clinics program prevalence study. Circulation 1980; 62, part II (suppl IV): 70-6.

${ }^{20}$ Førde OH, Thelle DS, Miller NE, Mjøs OD. The Troms $\varnothing$ heart study. Distribution of serum cholesterol between high density and lower density lipoproteins in subjects of Norse, Finnish and Lappish ethnic origin. Acta Med Scand 1978; 203: 21-6.

${ }^{21}$ Thelle DS, Førde OH. The cardiovascular study in Finnmark county: coronary risk factors and the occurrence of myocardial infarction in first degree relatives and in subjects of different ethnic origin. Am J Epidemiol 1979; 110: 708-15. 